\title{
Identifying Aspects of the Integration of Gus Durs's Religious Tourism Area with Regionalism Approaches
}

\author{
Jayanata Putra, Dewi Septanti, and Murni Rachmawati \\ Department of Architecture, Institut Teknologi Sepuluh Nopember, Surabaya \\ e-mail: jaydarmopermai@gmail,com
}

\begin{abstract}
Abstrak - Religious tourism is not separated from the activities which can affect the development of the region and can make it uncontrolled. Developments that can change significantly and uneven can harm various parties around the tourist area. Such developments can lead to a change in function and result in lifestyle shifts surrounding tourist areas. Therefore, integration is necessary for the establishment of a quality tourism plan in urban areas. Integration is an important aspect of changing in urban environments as it can create a space that has the attractiveness and mutual benefit between regions one and the other regions. The research method used is logical argumentation where the research relies on the argument as a reference in the aspects and results of research. Data collection techniques in research with interviews, observations, cognitive mapping and literature studies, after that done with data analysis using legibility analysis to identify the urban form in local and regional, sense of community identity and contributions or its role in the city then proceed with triangulation which aims to check the results of data test or data accuracy, then interpreted according to the context. This study results in what aspects can affect the change in tourist area functions and can be used as an integrated aspect of the surrounding environment.
\end{abstract}

Kata Kunci-Change Functions, Cognitive Mapping, Integration, Logical Argumentation.

\section{INTRODUCTION}

$\mathrm{J}$ OMBANG City is not separated from its culture that is pesantren. Any region that has a culture must have a conflict of individual interests that could harm the other party and the surrounding environment. With the conflict, the function changes. Changes in functions that make changes to areas that develop unevenly. In urban sciences often referred to as the rivalry of urban land that resulted in the shifting lifestyle of communities that originally gathered in open spaces, now moved to areas that have a certain interest. This shows the public open space as a gathering container for the community. The integration between locations is an important concern in the sphere of development.

Jombang is a city or small town that has a prominent factor in the element of forming the city and it serves as a center of community activity and has a historic experience. Jombang itself is better known by many people as a students city because in the area Jombang itself a lot of boarding schools scattered there and the grave of the great figure is $\mathrm{KH}$. Abdurrahman Wahid or often called by the call of Gus Dur. The typical preservation of Jombang city is an important factor in showing as the local identity of Jombang. According to Khotimah and Sri Sadewo in the presence of religious tourism complex there is a problem change related to local activities that have an impact on socio-cultural change due to tourism is seen from the traditions of local people itself [1]. Since the existence of religious tourism in the region Tebuireng make local people busy with their activities daily. With their busyness, the activities organized by local community village itself can not come to the event. As with the activities of mutual assistance held by the village, local people who have opened the field of trading in the tourist areas, many people who can not come and attend the event. Because the event held by the village is done on the day off. On holiday, Tebuireng area is crowded by tourists. The number of tourists who come to make local people who open business around the tomb, can not follow the activities of the village that is being held.

Integrated area is a relationship of some places that have their own advantages. The influential aspects are circulation, zone, and visuals. Integration can create a comfortable and useful area. The environment is a physical factor that contributes to the development of the region [7]. Tourism is an economic perspective that is in terms of demand (demand) and supply. Soebiyantoro et al.,defines tourism as the economic activity that must be seen from two sides namely demand side (demand side) and the supply side, further Gunn suggests that the success in tourism development in a region depends on the ability of the planner to integrate both sides in a balanced into a tourism development plan [4].

Based on the location of the study where the tour is not separated from the local elements that are bound by the Keregionalan location. According to Jenks (1977) in Soebiyantoro et al. Regionalism flourished around the year 1960 [4]. Regionalism (regional) emphasizes the disclosure of the characteristic of an area/place in contemporary architecture. This approach is used as a critique in modern architecture that only views the architecture is universal.

In the book Ching (2000) in Setyoaji, Rukayah and Supriyadi [2]. "A harmonious arrangement can be created by with A condition where each part of the whole architectural composition is interconnected, not just A mere geometric rule ". The city is a system that contains links between actors, functions and linkage. Based on the understanding of the system of the city area above then the integration factors will include the norms factor related to the 
The $6^{\text {th }}$ International Seminar on Science and Technology (ISST) 2020

July $25^{\text {th }}$ 2020, Institut Teknologi Sepuluh Nopember, Surabaya, Indonesia
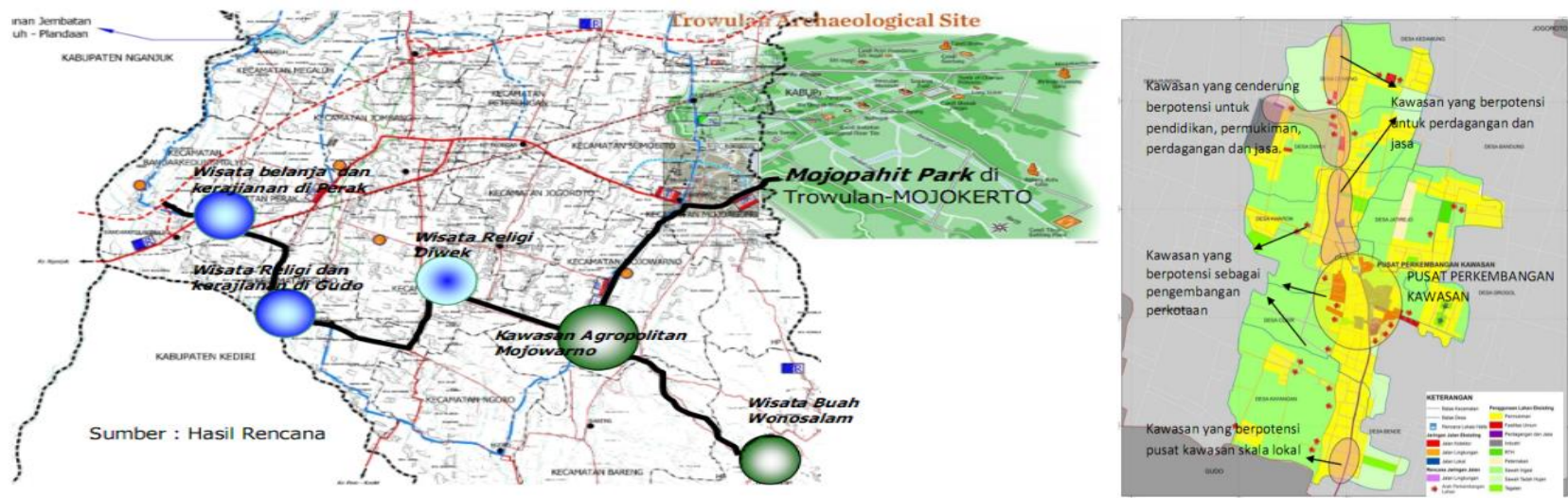

Figure 1. Development of study and path of tourist districts.

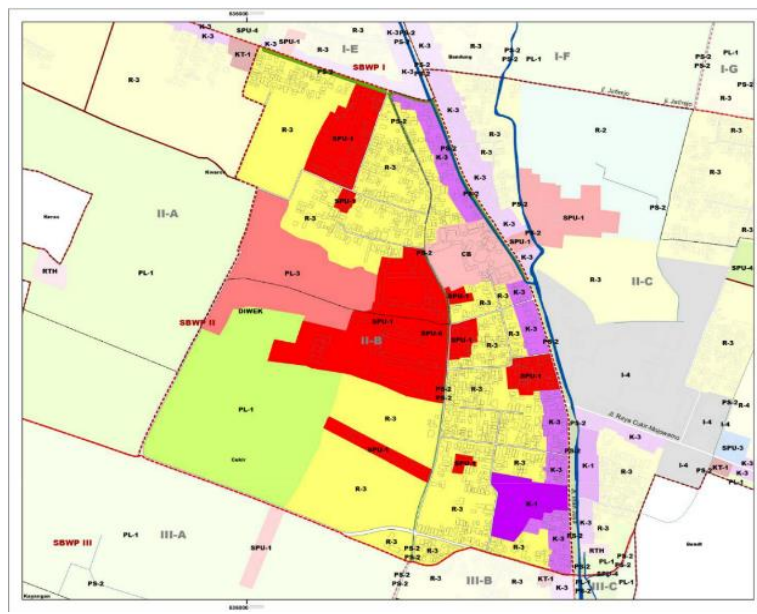

Figure 2. land used and site religious tourism area.

element of the perpetrator, the function factor related to the function of activities and physical factors related to the linkage [5].

The integrated city area is thus a region based on a contextual norm with the behavior of the people, culture and place. Integrating components on the norm factor (cultural, regulatory, institutional) requirements are required (Trancik [5]:

1. Describe the value of culture and behavior in the sense, copyright, Karsa. The region must connect physically with its cultural context and pay attention to the wishes and aspirations of society.

2. Be compliant with natural environment and social reality. The area is considered good if there is a limitation with the potential of the local people and demands and avoided zoning outside the wishes and context of the community.

3. Accommodate the form of social communities and community organization. The area can be used by people and diverse communities.

The explanation in the book "Design in Architecture" (1973), according to the Geoffrey Broadbent inside Surasetja, which divides the six types of functions that can be implemented by the architecture to know the demands of the function of the building/region [6].

1. Environmental Filter (modifier of the physical climate). Buildings can control the climate. The building acts as a sieve or filter between the outside environment and the activities we are going to do.

2. Container of Activities. Building as a container of activities that put it on the general criteria of Integrated planning Investment (Changer of land value). In this sense the building can provide more value on the tread. Both can be good sources of investment.

3. Symbolic Function (cultural implication). In this sense the building can provide symbolic values especially on activities that are religious or that are in the culturalimplication.

4. Behavior Modifier. In the behavior modifier function, the building can change behavior and habits, according to the atmosphere of the space.

5. Aesthetic Function (Pursuit of delight). In this sense buildings will be pleasant if the building looks $\mathrm{good} /$ beautiful, in accordance with the current fashionable imagination, in accordance with certain principles of visual order and others.

The study is included in regionalism as a critical stance (Critical Regionalism) of regional characteristics focusing on an area in contemporary architecture. Frampton further formulated the characteristics of Critical regionalism [3].

1. More important to the place that is concrete than the space that is abstract.

2. More concerned with the landscape (topography) than the form of the building (typology). 
The $6^{\text {th }}$ International Seminar on Science and Technology (ISST) 2020

July $25^{\text {th }} 2020$, Institut Teknologi Sepuluh Nopember, Surabaya, Indonesia

Table 1.

Integrated aspects of designing

\begin{tabular}{|c|c|c|c|}
\hline No & Definition & Aspects & Sub Aspek \\
\hline 1 & $\begin{array}{l}\text { Integration is a blend so that it } \\
\text { can become a unified whole } \\
\text { and rounded. It is a } \\
\text { harmonious arrangement that } \\
\text { can be created by arranging a } \\
\text { condition in which each part of } \\
\text { the whole architectural } \\
\text { composition is interconnected } \\
(\text { Ching, 2000). }\end{array}$ & $\begin{array}{l}\text { Integration } \\
\text { of religious } \\
\text { tourism area }\end{array}$ & $\begin{array}{l}\text { The Place Theory } \\
\text { - Cultural values } \\
\text { Describing cultural and behavioral values in taste, copyright, Carsa. The region must } \\
\text { connect physically with its cultural context and pay attention to the wishes and } \\
\text { aspirations of society. } \\
\text { - Regulations } \\
\text { Adhere to the Pranata according to natural environment and social reality. The area is } \\
\text { considered good if there is a limitation with the potential of the local people and } \\
\text { demands and avoided zoning outside the wishes and context of the community. } \\
\text { - Institutional } \\
\text { Accommodating social community and civic organizations. The area can be used by } \\
\text { people and diverse communities. }\end{array}$ \\
\hline 2 & $\begin{array}{l}\text { Architecture does not loose } \\
\text { with functions that affect the } \\
\text { activity of a space. An } \\
\text { architectural principle in } \\
\text { which the form of an } \\
\text { architecture must be obtained } \\
\text { from the function that must be } \\
\text { fulfilled (Form Follow } \\
\text { Function) }\end{array}$ & $\begin{array}{l}\text { Change of } \\
\text { function }\end{array}$ & $\begin{array}{l}\text { Container of Activities } \\
\text { Capital Investment } \\
\text { Symbolic Function }\end{array}$ \\
\hline 3 & $\begin{array}{l}\text { Critical regionalism is a } \\
\text { critical attitude to the human } \\
\text { concern of modernism and is } \\
\text { trying to restore architecture } \\
\text { into its surrounding context } \\
\text { and development, its goal of } \\
\text { strengthening local identity by } \\
\text { looking at the potential and } \\
\text { caring for the Environment }\end{array}$ & $\begin{array}{l}\text { The forming } \\
\text { of Critical } \\
\text { regionalism }\end{array}$ & $\begin{array}{l}\text { Place (Meaning and Value) } \\
\text { Topography (Manusia and Alam) }\end{array}$ \\
\hline
\end{tabular}

3. To be more concerned with the techniques of building an aesthetic, than the appearance of the form (scenographic) alone.

4. More natural importance (natural) than artificial.

5. More concerned with body and tentacle (tactile) than the visual alone.

\section{METHODOLOGY}

This research uses Logical Argumentation strategies and can underlie some of the theories used. To get a maximum research needed a data collection technique because data collection in the right way will produce maximum study. The technique used in the study of "Integrated designing religious tourism area of Wahid's tomb with regionalism approach" is to obtain primary data and secondary data: observation, documentation, historical studies, literature study and interviews.

\section{OVERVIEW}

Jombang itself is better known by many people as a students city because in the area Jombang itself a lot of boarding schools scattered there and the grave of the great figure is KH. Abdurrahman Wahid or often called by the call of Gus Dur. Development of study and path tourist districts can see Figure 1. The city of Jombang has a variety of Islamic educational institutions both non formal and formal since the early 18th century. Jombang is also the birthplace of national figures, among them the former president of Indonesia $\mathrm{KH}$. Abdurrahman Wahid later national hero KH. M Hasyim
Asyari, KH. A. Wahid Hasyim and KH. A. Wahab Chasbullah. Landused and site religious tourism area can see Figure 2.

The biggest potential is the function of a distinctive area and unique with local wisdom in the form of boarding school Tebu Ireng which is the attraction of the area and become one of the social development Center of the culture in the city Jombang. In addition, the area is a unique and distinctive area that is with the education center of the School of Tebu Ireng which becomes the attraction of people to gain knowledge in the Pesantren. The activity of the implement makes many problems and as a positive value for the surrounding community

\section{RESULT AND DISCUSION}

This research focuses on the search for any aspect that can be used as the development of tourist areas integrated with the surrounding environment. This aspect can later be utilized as a design plan for regional and regionalism based areas. This aspect is influenced by the state of the study site which is an important area because of the tomb of a former national figure of the RI-4 president and is a conservation area by the government and a new area within the scope of tourism destinations. Integrated aspects designing can see Table 1.

\section{CONCLUSION}

The conclusion of the study is an aspect that can be used as the identification of the location of study with the reference of the aspect that potentially as an integration of religious 
The $6^{\text {th }}$ International Seminar on Science and Technology (ISST) 2020

July $25^{\text {th }} 2020$, Institut Teknologi Sepuluh Nopember, Surabaya, Indonesia

tourism development. The aspect is the place Theory (Cultural values, Regulations, Institutional), Container of Activities, Capital Investment, Symbolic Function, Place (Meaning and Value), and Topography (Manusia and Alam) These aspects are later used to:(1)Placing value as a balance between human and natural;(2)Economic system as investment capital; (3)Alignment of symbolic values as place characters;(4)Open room to support all activities in the community.

\section{REFERENCES}

[1] Khotimah, N. and Sri Sadewo, F. (2017) 'Perubahan Sosial Masyarakat
Tebuireng Setelah Adanya Wisata Religi Makam Gus Dur'.

[2] Setyoaji, S. A., Rukayah, R. S. and Supriyadi, B. (2015) 'Tipologi dan Konsep Integrasi pada Lingkungan Bangunan Pendidikan dengan Karakter Arsitektur Kolonial di Jalan Kartini Kota Salatiga'.

[3] Sherlia and Wihardyanto, D. (2005) 'Perkembangan Konsep Regionalisme Kritis Kenneth Frampton (1985-2005)', 2(1).

[4] Soebiyantoro, U. et al. (2009) 'Pengaruh Ketersediaan Sarana Prasarana, Sarana Transportasi Terhadap Kepuasan Wisatawan', Manajemen Pemasaran.

[5] Soedwi (1995) 'Kawasan Kota yang Terintegrasi', pp. 1992-1994.

[6] Surasetja, R. I. (2007) 'Fungsi, Ruang, Bentuk dan Ekspresi dalam Arsitektur'.

[7] Widodo, B. and Lupyanto, R. (2011) 'Pengembangan Kawasan Pinggiran Kota dan Permasalahan Lingkungan di Kampung Seni Nitiprayan, Bantul', Jurnal Sains dan Teknologi Lingkungan ISSN: 2085-1227 